\title{
Isolation of Mycobacterium-reactive CD1-restricted T Cells from Patients with Human Immunodeficiency Virus Infection
}

\author{
Jianhua Gong, ${ }^{\star}$ Steffen Stenger, Jerome A. Zack," Brenda E. Jones, ${ }^{\S}$ Gregory C. Bristol," Robert L. Modlin," \\ Philip J. Morrissey, ${ }^{\star \star}$ and Peter F. Barnes ${ }^{\star \ddagger}$ \\ *Center for Pulmonary and Infectious Disease Control, ${ }^{\ddagger}$ Departments of Medicine and Cell Biology, The University of Texas Health \\ Center, Tyler, Texas 75710; ${ }^{\S}$ Division of Infectious Diseases, Department of Medicine, University of Southern California School of \\ Medicine, Los Angeles, California 90033; "Division of Dermatology, Department of Microbiology and Immunology, and ${ }^{\mathbb{I}}$ Department of \\ Medicine, UCLA School of Medicine, Los Angeles, California 90024; and **Immunex Corporation, Seattle, Washington 98101
}

\begin{abstract}
Because CD1-restricted T cells lack CD4 but produce IFN- $\gamma$ in response to nonpeptide mycobacterial antigens, they could play a unique role in immunity to tuberculosis. We studied CD1-restricted T cells in the context of HIV infection by expanding $\mathrm{CD}^{-} \mathrm{T}$ cell lines from $10 \mathrm{HIV}$-infected patients. Upon stimulation with Mycobacterium tuberculosis antigen or upon exposure to macrophages infected with $M$. tuberculosis, these $\mathrm{T}$ cell lines proliferated, produced IFN- $\gamma$, and showed cytolytic T cell (CTL) activity against macrophages pulsed with mycobacterial antigen, findings consistent with a protective role against $M$. tuberculosis. Anti-CD1b antibodies abrogated $T$ cell proliferation, IFN- $\gamma$ production, and CTL activity, demonstrating that these $\mathrm{T}$ cells are CD1 restricted. IFN- $\gamma$ production in response to $M$. tuberculosis was enhanced by antitransforming growth factor- $\beta$ in $8 / 10$ lines, and by IL-15 in $2 / 10$ lines. IFN- $\gamma$ production was augmented in a nonantigen-specific manner by IL-12 in 4/8 lines. When live HIV was cocultured with CD1restricted $\mathrm{T}$ cell lines, p24 antigen and proviral DNA were not detected, indicating that the $T$ cells were not infectable with HIV. Vaccination strategies aimed at activation and expansion of $M$. tuberculosis-reactive CD1-restricted T cells in HIV-infected patients may constitute a novel means to provide protection against tuberculosis, while minimizing the risk of enhancing HIV replication through stimulation of $\mathrm{CD}^{+}$cells. (J. Clin. Invest. 1998. 101:383-389.) Key words: CD1 $\bullet$ T cell $\bullet$ HIV $\bullet$ IFN- $\gamma \bullet$ immunotherapy
\end{abstract}

\section{Introduction}

HIV infection markedly increases susceptibility to tuberculosis (1), and tuberculosis in HIV-infected patients accelerates progression of immunodeficiency and hastens death (2). As the HIV pandemic spreads in developing countries, the deadly combination of tuberculosis and HIV infection is expected to cause $>1,400,000$ cases and 500,000 deaths in the year 2000

Address correspondence to Peter F. Barnes, Center for Pulmonary and Infectious Disease Control, The University of Texas Health Center at Tyler, P.O. Box 2003, Tyler, TX 75710-2003. Phone: 903-8775956; FAX: 903-877-7989; E-mail: pbarnes@uthct.edu

Received for publication 22 August 1997 and accepted in revised form 10 November 1997.

J. Clin. Invest.

(C) The American Society for Clinical Investigation, Inc. 0021-9738/98/01/0383/07 \$2.00

Volume 101, Number 2, January 1998, 383-389

http://www.jci.org
(3). Tuberculosis control efforts are hampered by delayed diagnosis, the cost of antituberculosis drugs, difficulty in ensuring completion of prolonged therapy, and increasing rates of drug resistance. Prevention of tuberculosis through vaccination is an alternative and cost-effective strategy that would contribute greatly to tuberculosis control among HIV-infected persons.

In HIV-infected patients, induction of immunity against infectious agents through vaccination is a double-edged sword because activation of the immune response can enhance retroviral replication and contribute to progressive HIV disease (4-6). Standard vaccination strategies are particularly problematic because they result in activation of $\mathrm{CD}^{+}$cells, which are the major reservoir for HIV. A rational vaccination strategy would be to upregulate the immune response by CD4-negative $\mathrm{T}$ cells that are not susceptible to HIV infection.

CD1 is a family of cell surface molecules that participate in antigen recognition by $\mathrm{T}$ cells. CD1 molecules are structurally related to $\mathrm{MHC}$ molecules, but are nonpolymorphic. A distinctive feature of human CD1 restricted T cells is their capacity to recognize nonprotein antigens (7-10). CD1-restricted $\mathrm{T}$ cells include $\mathrm{CD} 8^{+}$cells, $\mathrm{T}$ cells bearing the $\gamma \delta \mathrm{T}$ cell receptor (TCR), ${ }^{1}$ and $\mathrm{CD}^{-}{ }^{-} \mathrm{CD} 8^{-} \mathrm{T}$ cells bearing the $\alpha \beta$ TCR, all of which are CD4-negative $(10,11)$. Because CD1-restricted T cells lack CD4, they are a logical target for enhancement of the antimycobacterial immune response in HIV-infected patients. To determine the feasibility of this approach, we attempted to isolate Mycobacterium tuberculosis-reactive CD1-restricted T cells from HIV-infected patients.

\section{Methods}

Patient population. Blood was obtained from 13 outpatients with HIV infection, none of whom had active opportunistic infections or tumors. The median CD4 cell count was 286 cells/ $\mu$ l (range 120-543 cells $/ \mu \mathrm{l}$ ) and 10 patients were receiving antiretroviral therapy.

Preparation of sonicate of M. tuberculosis H37Rv. $200 \mathrm{mg}$ of gamma-irradiated M. tuberculosis H37Rv (provided by Dr. John Belisle, Colorado State University, Fort Collins, CO), was washed twice in $40 \mathrm{ml}$ of PBS, pelleted for $5 \mathrm{~min}$ at $800 \mathrm{~g}$, and resuspended in $4 \mathrm{ml}$ PBS in a $15 \mathrm{ml}$ conical tube. This preparation was sonicated continuously for $5 \mathrm{~min}$ in an ice water bath, then centrifuged for $5 \mathrm{~min}$ at $900 \mathrm{~g}$. The supernatant was collected and saved. The pellet was resuspended in $1 \mathrm{ml}$ PBS in a 15-ml conical tube, and sonicated for $1 \mathrm{~min}$ in an ice water bath. This second sonicate was combined with supernatant from the first sonicate, and ultracentrifuged for $1 \mathrm{~h}$ at $100,000 \mathrm{~g}$ at $4^{\circ} \mathrm{C}$. The supernatant was collected, filtered through a $0.2-\mu \mathrm{M}$ filter and the protein concentration measured by the Bradford assay. Approximately $1.6 \mathrm{mg}$ of protein was obtained from $200 \mathrm{mg}$ of $M$. tuberculosis H37Rv.

1. Abbreviations used in this paper: CTL, cytolytic T cell; TCR, T cell receptor. 
Establishment of CD1-restricted T cell lines. PBMC were isolated by differential centrifugation over Ficoll-Paque (Pharmacia Fine Chemicals, Piscataway, NJ). PBMC were incubated overnight at a concentration of $5 \times 10^{6}$ cells $/ \mathrm{ml}$ in a $25-\mathrm{ml}$ tissue culture flask in RPMI (Gibco, Grand Island, NY) containing penicillin/streptomycin (Gibco) and 10\% heat-inactivated human serum. Nonadherent cells were removed and cell suspensions incubated with magnetic beads conjugated to CD4, CD8, and CD16 (Dynal, Lake Success, NY). A magnetic cell separator was used to remove $\mathrm{CD}^{+}, \mathrm{CD}^{+}$, and $\mathrm{CD} 16^{+}$ cells, and negatively selected cells were incubated with anti-TCR- $\gamma \delta$ (Immunotech, Marseille, France), then with magnetic beads coated with goat anti-mouse IgG (Dynal). After immunomagnetic depletion of $\gamma \delta \mathrm{T}$ cells with a magnetic cell separator, we obtained $1-2 \times 10^{6}$ cells that were enriched for $\mathrm{CD}^{-} \mathrm{CD} 8^{-} \mathrm{T}$ cells expressing the $\alpha \beta$ TCR.

An aliquot of $2 \times 10^{6} \mathrm{PBMC}$ from each patient was used to derive $\mathrm{CD}^{+}$antigen-presenting cells by culture overnight in a 2-ml well in RPMI containing penicillin/streptomycin, 8\% FCS (HyClone Laboratories Inc., Logan, UT), 2\% heat-inactivated human serum, IL-4 (100 U/ml; a kind gift of the Schering Plough Corp., Kenilworth, NJ) and GM-CSF (200 U/ml; R \& D Systems, Minneapolis, MN) to induce CD1 expression. After incubation overnight, the supernatant was discarded, the cells were irradiated (5,000 rads) and $2 \mu \mathrm{g} / \mathrm{ml}$ of a sonicate of $M$. tuberculosis strain H37Rv was added. $2 \mathrm{~h}$ later, the $\mathrm{T}$ cells enriched for $\mathrm{CD} 4^{-} \mathrm{CD} 8^{-} \alpha \beta^{+}$cells were added to the irradiated antigen-presenting cells and cultured in $10 \%$ serum. This time point is considered to be day 0 . On day 3 or 4 , cells were centrifuged over Ficoll-Paque to enrich for lymphoblasts and further expanded with fresh serum (10\%) and IL-2 (10\%; Hemagen Diagnostics, Columbia, MD). On days 7 and 10, fresh serum and IL-2 were added. On day 14, M. tuberculosis antigen and allogeneic irradiated PBMC from healthy HIV-negative donors, pretreated with IL-4 and GMCSF for $3 \mathrm{~d}$, were added as antigen-presenting cells. The 2-wk cycle of addition of antigen and antigen-presenting cells, centrifugation over Ficoll-Paque, and expansion with IL-2 was repeated until adequate numbers of $\mathrm{T}$ cells were obtained. Cytofluorometric analysis was performed as outlined below. If $\mathrm{T}$ cell lines contained more than $20 \%$ $\mathrm{CD}^{+}, \mathrm{CD}^{+}$, or $\gamma \delta \mathrm{TCR}^{+}$cells, a second round of depletion was performed with magnetic beads conjugated to the appropriate antibodies, as outlined above. Most lines were tested for proliferation and cytokine production after two or three cycles of expansion.

Cytofluorometric analysis. T cell lines were stained with FITCconjugated anti-CD3, anti-CD4, anti-CD8 (all from Dako, Carpinteria, CA), anti-TCR $\alpha \beta$ and anti-TCR $\gamma \delta$ (both from Immunotech). Cells were incubated with the monoclonal antibodies on ice for 20 min, washed once with $10 \%$ FCS in RPMI, and analyzed by flow cytometry with a FACSTAR (Becton Dickinson Immunocytometry, San Jose, CA).

Cytokine production and proliferation in response to mycobacterial antigens. Proliferative and cytokine responses were evaluated at least $6 \mathrm{~d}$ after the $\mathrm{T}$ cell lines had received antigen and at least $3 \mathrm{~d}$ after they had received IL-2. For each assay, triplicate wells were established containing $2 \times 10^{4} \mathrm{~T}$ cells, $5 \times 10^{4}$ allogeneic irradiated feeders pretreated with GM-CSF and IL-4 for $3 \mathrm{~d}, 2 \mu \mathrm{g} / \mathrm{ml}$ of H37Rv sonicate and $10 \%$ human serum. In some experiments, IL-12 (10 ng/ml; kind gift of Dr. Maurice Gately, Hoffmann-La Roche, Nutley, NJ), IL-15 $(1 \mathrm{ng} / \mathrm{ml}$; provided by Immunex Corporation, Seattle, WA), anti-IL-4 (10 $\mu \mathrm{g} / \mathrm{ml}$; Pharmingen, San Diego, CA), anti-IL-10 (10 $\mu \mathrm{g} / \mathrm{ml}$; Biosource International, Camarillo, CA), anti-TGF- $\beta(10 \mu \mathrm{g} / \mathrm{ml})$, antiCD1a ( $\operatorname{IgG}_{1}$, OKT6 hybridoma; American Type Culture Collection [ATCC], Rockville, MD, $10 \mu \mathrm{g} / \mathrm{ml})$, anti-CD1b ( $\operatorname{IgG}_{1}, \mathrm{BCD} 1 \mathrm{~b} 3.1$ [12], $5 \mu \mathrm{g} / \mathrm{ml})$, anti-CD1c $\left(\operatorname{IgG}_{1}, 10 \mathrm{C} 3[10], 10 \mu \mathrm{g} / \mathrm{ml}\right)$, anti-MHC class I ( $\operatorname{IgG}_{2 \mathrm{a}}, \mathrm{W} 6 / 32$ hybridoma, ATCC, $\left.10 \mu \mathrm{g} / \mathrm{ml}\right)$ and anti-MHC class II ( $\mathrm{IgG}_{2 \mathrm{a}}, \mathrm{L} 243$ hybridoma, ATCC, $10 \mu \mathrm{g} / \mathrm{ml}$ ) were also added to the cell cultures. Proliferative responses were measured by incorporation of $\left[{ }^{3} \mathrm{H}\right]$ thymidine after $72 \mathrm{~h}$. Supernatants were harvested after $72 \mathrm{~h}$ and stored at $-70^{\circ} \mathrm{C}$ before assay of cytokine concentrations. IFN- $\gamma$ concentrations were measured by ELISA, using antibodies (kindly provided by Brian Paasch, Genentech, South San Francisco, CA). IL-4 concentrations were measured by ELISA, using antibodies purchased from Pharmingen. The sensitivities of these ELISAs were 6 and $5 \mathrm{pg} / \mathrm{ml}$ for IFN- $\gamma$ and IL-4, respectively.

In some experiments, PBMC from healthy donors were treated with GM-CSF and IL-4 for $3 \mathrm{~d}$ to induce CD1 expression, and adherent cells were detached and replated in 6-well plates at $3 \times 10^{6}$ cells per well. These adherent cells were infected with single cell suspensions of M. tuberculosis $\mathrm{H} 37 \mathrm{Rv}$ at a multiplicity of infection of $5: 1$, which resulted in infection of $\sim 85 \%$ of the macrophages, with approximately three bacteria per macrophage, as determined by Auramine-Rhodamine staining. Microscopic examination of infected macrophages confirmed the absence of mycobacterial aggregates. After $4 \mathrm{~h}$, extracellular bacteria were removed by extensive washing, infected cells were detached with $1 \mathrm{mM}$ EDTA and $2 \times 10^{4}$ cells were replated in triplicate in 200- $\mu$ l round-bottom wells. CD1-restricted $\mathrm{T}$ cells $\left(10^{4}\right)$ were added, and after $16 \mathrm{~h}$, supernatants were collected.

CTL assay. PBMC from healthy donors were treated with GMCSF and IL- 4 for $3 \mathrm{~d}$ to induce CD1 expression, and adherent cells were pulsed with soluble $M$. tuberculosis extract $(5 \mu \mathrm{g} / \mathrm{ml})$ overnight, detached with $1 \mathrm{mM}$ EDTA and labeled with $100 \mu \mathrm{Ci}{ }^{51} \mathrm{Cr}$ (ICN, Costa Mesa, CA) for $1 \mathrm{~h}$. After two washes, labeled cells were plated in 200- $\mu \mathrm{l}$ round-bottom wells at $4 \times 10^{3}$ cells/well. CD1-restricted T cells were added at an effector/target ratio of 7:1, and in some cases, neutralizing antibodies to CD1a, CD1b, or CD1c were added $30 \mathrm{~min}$ before addition of the T cells. After incubation of the effectors and targets for $4 \mathrm{~h}$, target cell lysis was quantitated according to the formula [(cpm release from experimental $-\mathrm{cpm}$ from spontaneous release)/maximal release $-\mathrm{cpm}$ from spontaneous release) $\times 100$ ]. The spontaneous ${ }^{51} \mathrm{Cr}$ release by macrophages in the absence of $\mathrm{T}$ cells was $<15 \%$

Infection of CD1-restricted T cells with HIV. The HIV strains used were $\mathrm{HIV}-1_{\mathrm{NL} 4-3}$, an aggressive strain tropic only for $\mathrm{CD} 4^{+} \mathrm{T}$ cells (13) and HIV- $1_{\text {JR-CSF}}$, a less aggressive strain tropic for both $\mathrm{CD}^{+}$ cells and macrophages (14). Infections were performed as previously described $(15,16)$. Briefly, HIV-1 (200 ng of p24/106 target cells) was incubated with PHA-stimulated PBMC or CD1-restricted T cell line cells for $2 \mathrm{~h}$ in the presence of polybrene to facilitate virus attachment. Cells were then washed and cultured for $10 \mathrm{~d}$ in media containing serum and IL-2. Cell supernatants were harvested after $10 \mathrm{~d}$ and p24 gag antigen measured by ELISA (Coulter Immunology, Hialeah, FL).

Because measurement of p24 expression can be affected by the activation state or replication rate of the target cells, we used an alternative assay that measures synthesis of viral DNA in both $\mathrm{G}_{0}$ quiescent and activated cells (16). This assay measures the ability of HIV to enter and infect target cells, independent of cellular replication or activation state. Quantitative PCR for proviral DNA was performed on CD1-restricted T cells $20 \mathrm{~h}$ after infection with HIV-1, as previously described (16). Briefly, DNA from infected cells was amplified with radiolabeled primers specific for sequences from the HIV-1 long terminal repeat and from human $\beta$-globin. PCR products were resolved on a $6 \%$ polyacrylamide gel and radioactivity quantitated with an AMBIS radioanalytic image analysis system. Values from samples were compared with standard curves for HIV-1 long terminal repeat and $\beta$-globin, generated by amplification of known amounts of cloned HIV-1 DNA and DNA from uninfected PBMC, respectively. After normalization according to the $\beta$-globin PCR product, the number of HIV sequences per 100,000 cells was calculated. A background control consisted of cells incubated with heat-killed HIV- $1\left(60^{\circ} \mathrm{C}\right.$ for 40 min) to assess the level of contaminating HIV DNA in the virus stock used for infection.

\section{Results}

Establishment of M. tuberculosis-reactive CD1-restricted T cell lines from HIV-infected patients. We established $\mathrm{T}$ cell lines that proliferated in response to $M$. tuberculosis sonicate from $10 \mathrm{HIV}$-infected donors. Antigen-reactive T cell lines could 


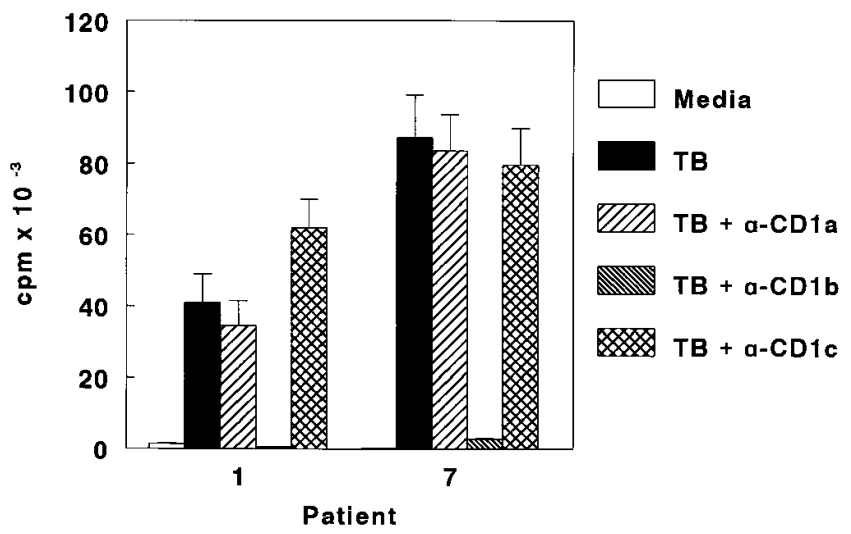

Figure 1. Effect of anti-CD1 antibodies on the proliferative response to M. tuberculosis by two CD1-restricted T cell lines from HIVinfected patients. CD1-restricted T-cell lines were cocultured with sonicated $M$. tuberculosis (TB), in the absence or presence of neutralizing antibodies to $\mathrm{CD} 1$ isoforms. Proliferative responses were measured by incorporation of $\left[{ }^{3} \mathrm{H}\right]$ thymidine. Mean values \pm SEM are shown.

not be established from three donors, whose clinical characteristics were similar to those from whom $\mathrm{T}$ cell lines were successfully established. The lines were $\mathrm{CD}^{+}, \alpha \beta \mathrm{TCR}^{+}, \mathrm{CD}^{-}$ by flow cytometry, and the percentage of $\gamma \delta \mathrm{TCR}^{+}$cells was 0-3\%. Nine lines were $\mathrm{CD} 8^{-}$and one was $\mathrm{CD} 8^{+}$. The mean proliferative response $( \pm \mathrm{SEM})$ of these lines in the presence of media alone was $1,450 \pm 621 \mathrm{cpm}$, and mean delta cpm to $M$. tuberculosis sonicate was $19,389 \pm 7,587$. In two representative $\mathrm{T}$ cell lines, antibodies to $\mathrm{CD} 1 \mathrm{~b}$ markedly reduced proliferation in response to $M$. tuberculosis, whereas anti-CD1a and anti-CD1c did not (Fig. 1). The capacity of anti-CD1b to block proliferative responses to $M$. tuberculosis was confirmed by testing all $10 \mathrm{~T}$ cell lines (Fig. 2).

Cytokine production by $M$. tuberculosis-reactive CD1restricted $T$ cell lines. Because IFN- $\gamma$ production is crucial for immunity against $M$. tuberculosis $(17,18)$, we investigated the capacity of these CD1-restricted T cells to produce cytokines

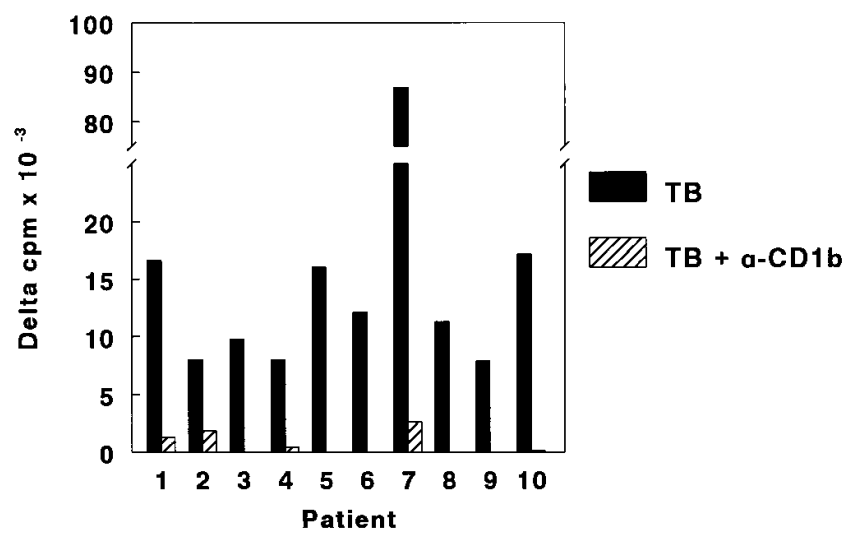

Figure 2. Effect of anti-CD1b antibodies on the proliferative response to M.tuberculosis of CD1-restricted T cell lines from HIVinfected patients. CD1-restricted T cell lines were cocultured with sonicated M. tuberculosis $(T B)$, in the absence or presence of neutralizing antibodies to $\mathrm{CD} 1 \mathrm{~b}$. Proliferative responses were measured by incorporation of $\left[{ }^{3} \mathrm{H}\right]$ thymidine. Mean values \pm SEM are shown.

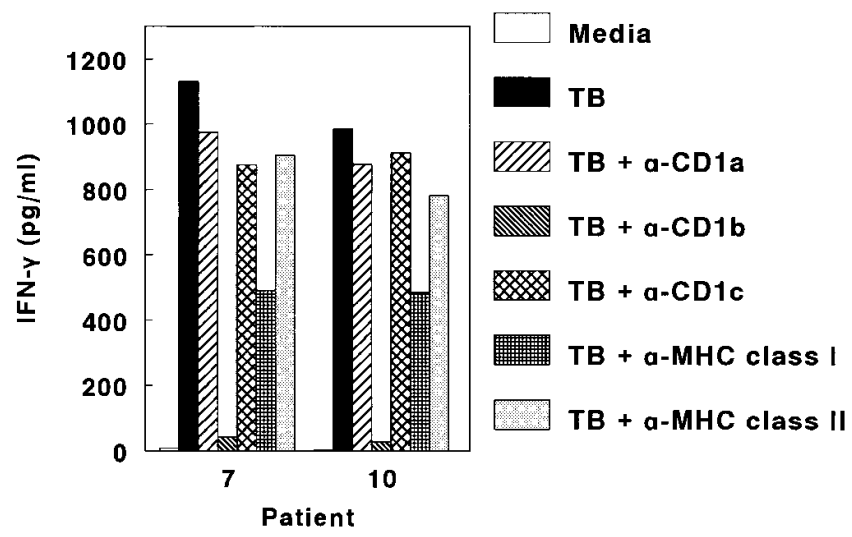

Figure 3. Effect of anti-CD1 and anti-MHC antibodies on M. tuberculosis-induced IFN- $\gamma$ production by CD1-restricted T cell lines. CD1-restricted T cell lines were cocultured with sonicated $M$. tuberculosis $(T B)$, in the absence or presence of neutralizing antibodies to $\mathrm{CD} 1$ isoforms, or to MHC class I or class II. IFN- $\gamma$ concentrations were measured by ELISA.

in response to $M$. tuberculosis sonicate. Five of five T cell lines produced $91-506 \mathrm{pg} / \mathrm{ml}$ of IFN- $\gamma$, compared to $3-15 \mathrm{pg} / \mathrm{ml}$ of IL-4, a cytokine pattern typical of Th1 cells. The mean IFN- $\gamma$ concentration produced by nine $\mathrm{T}$ cell lines was $719 \pm 317 \mathrm{pg} / \mathrm{ml}$, and this was reduced to $13 \pm 6 \mathrm{pg} / \mathrm{ml}$ when anti-CD1b was added, indicating that IFN- $\gamma$ was produced by CD1b-restricted $T$ cells. In two $\mathrm{T}$ cell lines, anti-CD1b reduced $M$. tuberculosisinduced IFN- $\gamma$ production to baseline levels, whereas antiCD1a, anti-CD1c, and anti-MHC class II antibodies had no effect (Fig. 3). Anti-MHC class I antibodies partially inhibited IFN- $\gamma$ production.

The experiments above demonstrate that CD1-restricted T cells from HIV-infected patients produce IFN- $\gamma$ in response to soluble $M$. tuberculosis antigens. To confirm the relevance of these findings to infection with $M$. tuberculosis in vivo, we cocultured CD1-restricted T cells with CD1-expressing macrophages infected with live M. tuberculosis. In two experiments,

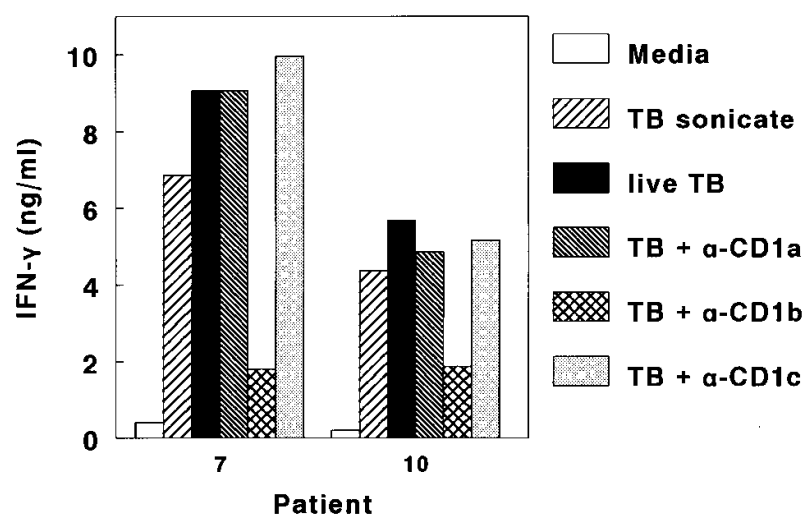

Figure 4. Effect of anti-CD1 antibodies on IFN- $\gamma$ production by CD1-restricted $\mathrm{T}$ cell lines upon exposure to macrophages infected with live M. tuberculosis. CD1-restricted T cell lines were cocultured with macrophages and M. tuberculosis $(T B)$ sonicate, or with macrophages infected with live $M$. tuberculosis, in the absence or presence of neutralizing antibodies to CD1 isoforms. IFN- $\gamma$ concentrations were measured by ELISA. 

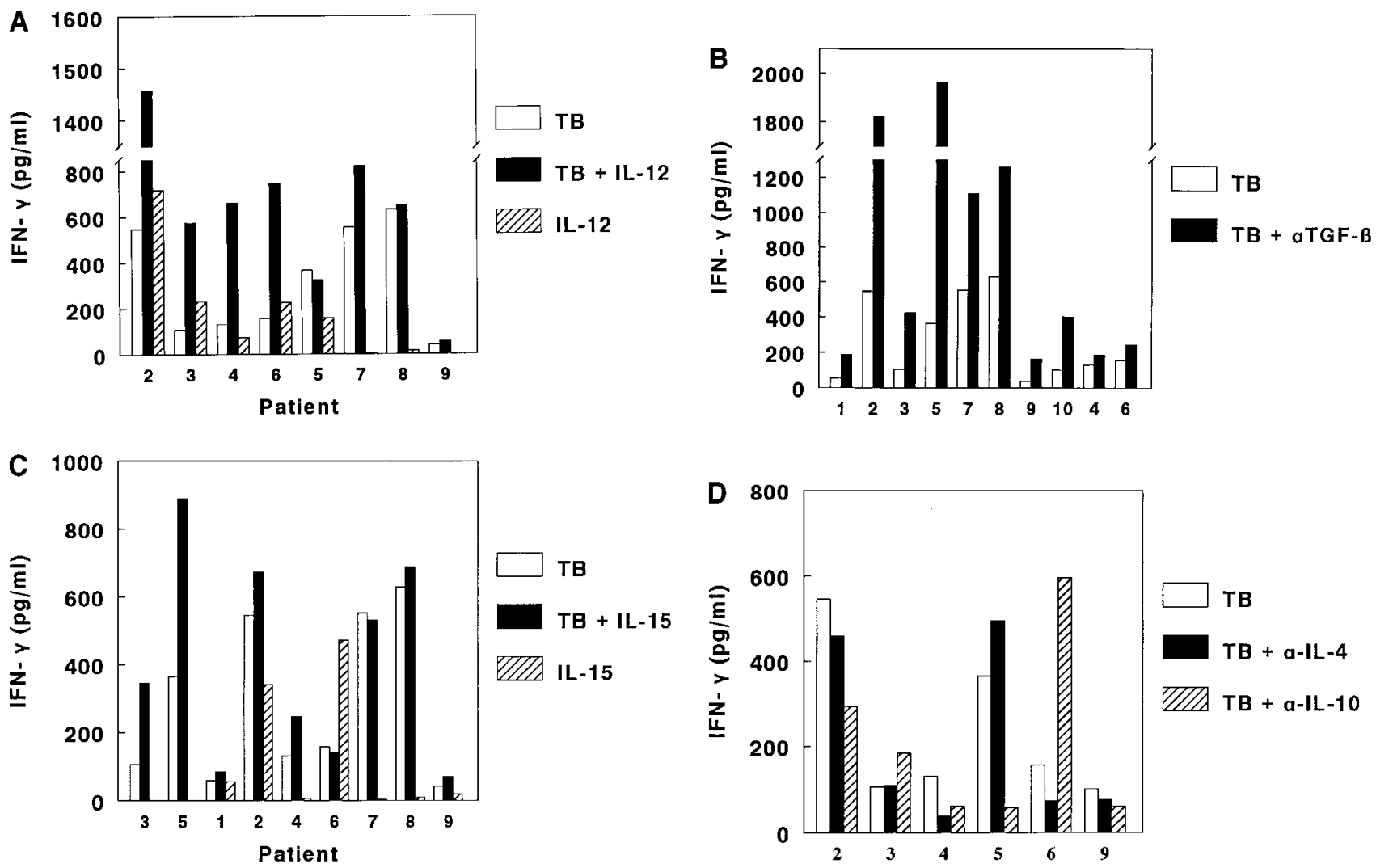

Figure 5. Modulation of IFN (IFN)- $\gamma$ production by CD1-restricted T cell lines, using IL-12 ( $A$ ), anti-TGF- $\beta$ (B), IL-15 (C), or anti-IL-4 and anti-IL-10 $(D)$. T cell lines were cultured in the presence of sonicated $M$. tuberculosis $(T B)$, with or without the cytokine or anticytokine antibodies. For IL-12 and IL-15, IFN- $\gamma$ production in the presence of cytokine alone without M. tuberculosis is also shown.

interferon- $\gamma$ concentrations produced by $\mathrm{T}$ cell lines were similar to those produced by $\mathrm{T}$ cell lines exposed to $M$. tuberculosis sonicate, and were specifically abrogated by anti-CD1b, but not by anti-CD1a or anti-CD1c (Fig. 4).

Modulation of IFN- $\gamma$ production in response to $M$. tuberculosis. Because IFN- $\gamma$ plays a central role in the immune response against $M$. tuberculosis, we attempted to enhance IFN- $\gamma$ production by the lines from HIV-infected patients by modulating the concentration of cytokines that affect IFN- $\gamma$ production by T cells from HIV-negative persons.

Interleukin-12 enhances IFN- $\gamma$ production by peripheral blood $\mathrm{T}$ cells in response to mycobacterial antigens in HIVinfected and HIV-negative tuberculosis patients (19) and IL-12 production in response to antigen is depressed in HIVinfected patients (20). Addition of IL-12 and M. tuberculosis sonicate to CD1-restricted lines enhanced IFN- $\gamma$ production three- to sixfold in 4 of 8 lines (patients 2, 3, 4, and 6; Fig. 5, A). However, the increased IFN- $\gamma$ production was not antigen specific, as addition of IL-12 alone in the absence of antigen also significantly boosted IFN- $\gamma$ production.

Transforming growth factor- $\beta$ is a potent immunosuppressive cytokine that is produced by macrophages in response to mycobacterial antigens $(21,22)$, and TGF- $\beta$ inhibits IFN- $\gamma$ production in response to mycobacterial antigens (23). Addition of neutralizing antibodies to TGF- $\beta$ enhanced $M$. tuberculosis-induced IFN- $\gamma$ production two- to fivefold in 8 of 10 lines (patients 1-3, 5, 7-10; Fig. 5, B). This enhancement was anti- gen specific as anti-TGF- $\beta$ in the absence of antigen did not elicit IFN- $\gamma$ production (data not shown). Mean IFN- $\gamma$ production in response to $M$. tuberculosis sonicate was $269 \pm 77 \mathrm{pg} / \mathrm{ml}$, compared with $776 \pm 235 \mathrm{pg} / \mathrm{ml}$ in response to $M$. tuberculosis and anti-TGF- $\beta(P=0.01$, paired $t$ test $)$.

Interleukin-15 is a potent $\mathrm{T}$ cell growth factor that shares many biologic activities with IL-2 and is an attractive agent to modulate the immune response in HIV-infected patients. Interleukin-2 enhances spontaneous and antigen-induced proliferation by $\mathrm{T}$ cells from HIV-infected patients, and induces HIV expression in vitro (24). In contrast, IL-15 specifically enhances antigen induced but not spontaneous proliferation by T cells from HIV-infected donors, and does not induce HIV expression in most patients (24). When IL-15 was added to $M$. tuberculosis-stimulated CD1-restricted lines, IFN- $\gamma$ production was enhanced two- to threefold in only 2 of 10 lines (patients 3 and 5; Fig. 5, C). However, the response was antigen specific in those patients, as IL-15 alone did not elicit IFN- $\gamma$ production.

In some experimental systems, the Th2 cytokines IL-4 and IL-10 downregulate production of IFN- $\gamma$ in response to mycobacteria $(25,26)$, and neutralization of these cytokines enhances lymphocyte proliferation and IL-2 production in HIV-infected patients $(27,28)$. However, addition of anti-IL-4 antibodies had no effect on M. tuberculosis-induced IFN- $\gamma$ production by the CD1-restricted T cell lines from HIV-infected patients, and anti-IL-10 increased IFN- $\gamma$ production in only 




Figure 6. CTL activity of two CD1-restricted T cell lines against macrophages pulsed with $M$. tuberculosis antigens. CD1-restricted T cells were cocultured with CD1-expressing macrophages pulsed with media alone or with $M$. tuberculosis sonicate at an effector/target ratio of 7:1. CTL activity was measured in triplicate, as the percent specific lysis, using a ${ }^{51} \mathrm{Cr}$ release assay, in the presence or absence of antibodies to $\mathrm{CD} 1$ isoforms. Mean values $\pm \mathrm{SEM}$ are shown.

one of six T cell lines (patient 6; Fig. 5,D). Anti-IL-4 and antiIL-10 did not elicit IFN- $\gamma$ production in the absence of $M$. tuberculosis (data not shown).

In summary, neutralization of TGF- $\beta$ was the most effective means to enhance $M$. tuberculosis-induced IFN- $\gamma$ production by CD1-restricted T cell lines from HIV-infected patients. In contrast, neutralization of IL-4 and IL-10 had no effect. Interleukin-12 and IL-15 enhanced IFN- $\gamma$ production in some lines, and the effect of IL-15 was antigen specific, whereas that of IL-12 was not. Because we studied T cell lines that were not $100 \%$ phenotypically pure, we cannot exclude the possibility that the enhancement of IFN- $\gamma$ production by cytokines and anticytokine antibodies was due in part to effects on cells other than CD1-restricted T cells.

CTL activity of CD1-restricted T cells. As an additional means to assess the capacity of CD1-restricted T cells to contribute toward immune defenses against tuberculosis, we measured CTL activity against CD1-expressing macrophages pulsed with M. tuberculosis antigens. Both T cell lines tested showed antigen-specific CTL activity, which was specifically inhibited by anti-CD1b (Fig. 6).

CD1-restricted $T$ cells do not support growth of HIV. To determine if HIV could infect the CD1-restricted T cells, we cocultured HIV with the T cell lines and with normal PBMC. Infection of PBMC from normal donors with the two HIV-1 strains resulted in production of $21-187 \mathrm{ng} / \mathrm{ml}$ of p24 in culture supernatants. In contrast, infection of three CD1-restricted T cell lines derived from HIV-infected donors did not result in detectable p24 expression (Table I).

Because p24 expression can be affected by the activation state or replication rate of the target cells, we performed quantitative PCR for proviral DNA, an alternative assay that measures the ability of HIV to enter and infect target cells, independent of cellular replication or activation state (Table II). Although virus stocks were pretreated with DNAse to limit the amount of contaminating viral DNA, 15-105 copies of viral DNA were present in cells treated with heat-killed virus. When live virus was added to normal PBMC, 19,000 copies of
Table I. Culture of HIV-1 in CD1-restructed T Cell Lines*

\begin{tabular}{llr}
\hline Virus strain & Cells & p24 \\
\hline & & $n g / m l$ \\
Experiment 1 & & \\
NL4-3 & PBMC & 97 \\
NL4-31 & Line 1 & 0 \\
JR-CSF & PBMC & 187 \\
JR-CSF & Line 1 & 0 \\
Experiment 2 & & \\
JR-CSF & PBMC & 21 \\
JR-CSF & Line 2 & 0 \\
JR-CSF & Line 3 & 0 \\
& &
\end{tabular}

*Normal PBMC or CD1-restriced T cell lines were infected with two strains of HIV-1 and cultured for $10 \mathrm{~d}$. p24 antigen concentrations were measured by ELISA.

HIV $_{\text {NL4-3 }}$ DNA and 600 copies of HIV $_{\text {JR-CSF }}$ were detected. When these HIV strains were used to infect a CD1-restricted $\mathrm{T}$ cell line, proviral DNA levels were similar to background levels (44-65 copies), confirming that these lines were not infectable with HIV.

\section{Discussion}

We report that $M$. tuberculosis-reactive CD1-restricted T cells can be expanded from HIV-infected patients. These T cells produced IFN- $\gamma$ in response to macrophages infected with live $M$. tuberculosis, and showed CTL activity against macrophages pulsed with $M$. tuberculosis antigens, consistent with a protective role against $M$. tuberculosis. Antigen-specific IFN- $\gamma$ production was enhanced in most $\mathrm{T}$ cell lines by neutralization of TGF- $\beta$, and in a minority of T cell lines by IL-15. The CD1restricted $\mathrm{T}$ cell lines were $\alpha \beta \mathrm{TCR}^{+} \mathrm{CD}^{-}$and were not infectable with HIV.

CD1 proteins are structurally related to MHC class I and class II proteins and play a role in antigen recognition by $\mathrm{T}$ cells. Antigens recognized by CD1-restricted T cells may be particularly useful for inclusion in an antituberculosis vaccine for HIV-infected patients. First, CD1 molecules are nonpolymorphic so that CD1-restricted antigens are likely to be recognized

Table II. Quantitation of HIV-1 in CD1-restricted T-cell lines by $P C R^{*}$

\begin{tabular}{llc}
\hline \multicolumn{1}{c}{ Virus strain } & Cells & HIV-1 copies per $10^{5}$ cells \\
\hline Killed NL4-3 & PBMC & 54 \\
Live NL4-31 & PBMC & 19034 \\
Killed NL4-3 & Line 1 & 15 \\
Line NL4-3 & Line 1 & 44 \\
Killed JR-CSF & PBMC & 80 \\
Live JR- CSF & PBMC & 594 \\
Killed JR-CSF & Line 1 & 105 \\
Live JR- CSF & Line 1 & 65 \\
& & \\
\hline
\end{tabular}

*Normal PBMC or a CD1-restriced T cell line were infected with heatkilled or live HIV-1 virus strains for $20 \mathrm{~h}$, and quantitative PCR performed to detect proviral DNA. 
by most individuals, whereas MHC-restricted antigens are generally recognized only by persons whose cells bear specific MHC molecules. Second, human CD1-restricted T cells include $\mathrm{CD} 4^{-} \mathrm{CD} 8^{-} \alpha \beta$ T cells, $\mathrm{CD} 8^{+}$cells, and $\gamma \delta \mathrm{T}$ cells, but apparently not $\mathrm{CD}^{+}$cells $(10,11)$, so that stimulation of CD1restricted $\mathrm{T}$ cells should not activate $\mathrm{CD}^{+}$cells or upregulate HIV replication. Third, CD1-restricted $\mathrm{T}$ cells from normal donors and from HIV-infected patients (data not shown) recognize nonpeptide lipid or glycolipid antigens (7-9) which do not elicit proliferation and cytokine production by $\mathrm{CD} 4^{+}$cells, so that vaccination with these antigens is unlikely to activate $\mathrm{CD}^{+}$cells. Vaccination strategies that upregulate the response of CD1-restricted $\mathrm{T}$ cells represent a novel means to provide protection against tuberculosis in HIV-infected patients, while minimizing the risk of enhancing HIV replication through stimulation of $\mathrm{CD} 4^{+}$cells.

$\mathrm{T}$ cells contribute to immune defenses against tuberculosis through production of the macrophage-activating factor IFN- $\gamma$ $(17,18,29,30)$ or through direct lysis of $M$. tuberculosis-infected macrophages (31-33). In this report, CD1-restricted T cells isolated from HIV-infected patients produced IFN- $\gamma$ in response to $M$. tuberculosis-infected macrophages and lysed macrophages exposed to mycobacterial antigens, suggesting that they have the capacity to provide protective immunity against tuberculosis. IFN- $\gamma$ production was completely blocked by anti-CD1b antibodies, but unaffected by anti-CD1a, antiCD1c, or anti-MHC class II antibodies. Anti-MHC class I antibodies partially blocked IFN- $\gamma$ production, but to a much smaller degree than anti-CD1b antibodies. CD1-restricted $\mathrm{T}$ cells express $\mathrm{CD} 8 \alpha$ but not $\mathrm{CD} 8 \beta$ (7), and $\mathrm{CD} 8 \alpha \alpha$ homodimers bind MHC class I $(34,35)$. It is possible that CD8 $\alpha \alpha$ homodimers and MHC class I molecules stabilize the interaction between the TCR and the antigen-presenting cell in CD1restricted $\mathrm{T}$ cells, and anti-MHC class I antibodies may interfere with this process and hence decrease IFN- $\gamma$ production.

Further studies are needed to fully understand the contribution of CD1-restricted T cells to protective immunity against tuberculosis in vivo. A critical measure of the immunologic significance of a cell subpopulation is its precursor frequency. It will therefore be important to determine the precursor frequency of $M$. tuberculosis-reactive CD1-restricted T cells in HIV-infected patients. This has not yet been achieved because it is difficult to separate the responses of CD1-restricted and MHC-restricted $\mathrm{T}$ cells in a limiting dilution assay. The establishment and immunologic evaluation of CD1-restricted T cell clones from HIV-infected patients is a second area of investigation that would permit more evaluation of cellular function at the single cell level, and permit a more detailed understanding of the functional capacity of these cells.

\section{Acknowledgments}

We thank Dr. Maurice Gately for providing recombinant IL-12, Drs. Samuel Behar and Walter Knapp for anti-CD1 antibodies, Brian Paasch and Genentech Inc. for provision of antibodies to IFN- $\gamma$, Dr. John Belisle for providing M. tuberculosis, and Claudia Silva, R.N. for assistance in obtaining patient blood samples.

This work was supported by the the National Institutes of Health (NIH) (grants AI 27285, AI 36069, and AI 33259) and the National Center for Research Resources General Clinical Research Centers grant M01 RR-43 (Minority Clinical Associate Physician), the UNDP/World Bank/World Health Organization Special Programme for Vaccine Development (IMMMYC), the Heiser Program for Re- search in Leprosy and Tuberculosis, and the German Cancer Research Center, Heidelberg, Germany. Molecular core laboratory facilities were provided by the NIH National Center for Research Resources of the General Clinical Research Centers grant M01 RR-43. Mycobacterial products were provided through contract AI 05074 from the National Institute of Allergy and Infectious Diseases.

\section{References}

1. Barnes, P.F., A.B. Bloch, P.T. Davidson, and D.E. Snider, Jr. 1991. Tuberculosis in patients with human immunodeficiency virus infection. $N$. Engl. J. Med. 324:1644-1650.

2. Whalen, C., C.R. Horsburgh, D. Hom, C. Lahart, M. Simberkoff, and J. Ellner. 1995. Accelerated course of human immunodeficiency virus infection after tuberculosis. Am. J. Respir. Crit. Care. Med. 151:129-135.

3. Raviglione, M.C., D.E. Snider, and A. Kochi. 1995. Global epidemiology of tuberculosis. Morbidity and mortality of a worldwide epidemic. J. Am. Med. Assoc. 273:220-226.

4. Stanley, S.K., M.A. Ostrowski, J.S. Justement, K. Gantt, S. Hedayati, M. Mannix, K. Roche, D.J. Schwartzentruber, C.H. Fox, and A.S. Fauci. 1996. Effect of immunization with a common recall antigen on viral expression in patients infected with human immunodeficiency virus type 1. N. Engl. J. Med. 334: 1222-1230.

5. Fauci, A.S. 1996. Host factors and the pathogenesis of HIV-induced disease. Nature. 384:529-534.

6. Weissman, D., T.D. Barker, and A.S. Fauci. 1996. The efficiency of acute infection of $\mathrm{CD}^{+} \mathrm{T}$ cells is markedly enhanced in the setting of antigen-specific immune activation. J. Exp. Med. 183:687-692.

7. Porcelli, S., C.T. Morita, and M.B. Brenner. 1992. CD1b restricts the response of human CD4-CD8- T lymphocytes to a microbial antigen. Nature. 360: 593-597.

8. Beckman, E.M., S.A. Porcelli, C.T. Morita, S.M. Behar, S.T. Furlong, and M.B. Brenner. 1994. Recognition of a lipid antigen by CD1-restricted $\alpha \beta^{+} \mathrm{T}$ cells. Nature. 372:691-694.

9. Sieling, P.A., D. Chatterjee, S.A. Porcelli, T.I. Prigozy, R.J. Mazzaccaro, T. Soriano, B.R. Bloom, M.B. Brenner, M. Kronenberg, P.J. Brennan, and R.L. Modlin. 1995. CD1-restricted T cell recognition of microbial lipoglycan antigens. Science. 269:227-230.

10. Beckman, E.M., A. Melian, S.M. Behar, P.A. Sieling, D. Chatterjee, S.T. Furlong, R. Matsumoto, J.P. Rosat, R.L. Modlin, and S.A. Porcelli. 1996. Evidence for antigen presentation by a second member of the human CD1 family. J. Immunol. 157:2795-2803.

11. Porcelli, S.A., and R.L. Modlin. 1995. CD1 and the expanding universe of T cell antigens. J. Immunol. 155:3709-3710.

12. Behar, S.M., S.A. Porcelli, E.M. Beckman, and M.B. Brenner. 1995. A pathway of costimulation that prevents anergy in $\mathrm{CD}_{2} 8^{-} \mathrm{T}$ cells: B7-independent costimulation of CD1-restricted T cells. J. Exp. Med. 182:2007-2018.

13. Adachi, A., H.E. Gendelman, S. Koenig, T. Folks, R. Willey, A. Rabson, and M.A. Martin. 1997. Production of acquired immunodeficiency syndrome-associated retrovirus in human and non-human cells transfected with a molecular clone. J. Virol. 59:284-291.

14. Koyanagi, Y., S. Miles, R.T. Mitsuyasu, J.E. Merrill, H.V. Vinters, and I.S.Y. Chen. 1987. Dual infection of the central nervous system by AIDS viruses with distinct cellular tropisms. Science. 236:819-882.

15. Zack, J.A., A.J. Cann, J.P. Lugo, and I.S.Y. Chen. 1988. HIV-1 production from infected peripheral blood T cells after HTLV-I induced mitogenic stimulation. Science. 240:1026-1029.

16. Zack, J.A., S.J. Arrigo, S.R. Weitsman, A.S. Go, A. Haislip, and I.S.Y. Chen. 1990. HIV-1 entry into quiescent primary lymphocytes: molecular analysis reveals a labile, latent viral structure. Cell. 61:213-222.

17. Cooper, A.M., D.K. Dalton, T.A. Stewart, J.P. Griffin, D.G. Russell, and I.M. Orme. 1993. Disseminated tuberculosis in interferon- $\gamma$ gene-disrupted mice. J. Exp. Med. 178:2243-2247.

18. Flynn, J.L., J. Chan, K.J. Triebold, D.K. Dalton, T.A. Stewart, and B.R. Bloom. 1993. An essential role for interferon- $\gamma$ in resistance to Mycobacterium tuberculosis infection. J. Exp. Med. 178:2249-2254.

19. Gong, J., M. Zhang, R.L. Modlin, P.S. Linsley, D. Iyer, Y. Lin, and P.F. Barnes. 1996. Interleukin-10 downregulates Mycobacterium tuberculosis-induced Th1 responses and CTLA-4 expression. Infect. Immun. 64:913-918.

20. Chehimi, J., S.E. Starr, I. Frank, A. D'andrea, X. Ma, R.R. MacGregor, J. Sennelier, and G. Trinchieri. 1994. Impaired interleukin-12 production in human immunodeficiency virus-infected patients. J. Exp. Med. 179:1361-1366.

21. Dahl, K.E., H. Shiratsuchi, B.D. Hamilton, J.J. Ellner, and Z. Toossi. 1996. Selective induction of transforming growth factor $\beta$ in human monocytes by lipoarabinomannan of Mycobacterium tuberculosis. Infect. Immun. 64:399-405.

22. Toossi, Z., T. Young, L.E. Averill, B.D. Hamilton, H. Shiratsuchi, and J.J. Ellner. 1995. Induction of transforming growth factor $\beta 1$ by purified protein derivative of Mycobacterium tuberculosis. Infect. Immun. 63:224-228.

23. Hirsch, C.S., R. Hussain, Z. Toossi, G. Dawood, F. Shahid, and J.J. Ellner. 1996. Cross-modulation by transforming growth factor $\beta$ in human tuber- 
culosis: Suppression of antigen-driven blastogenesis and IFN $\gamma$ production. Proc. Natl. Acad. Sci. USA. 93:3193-3198.

24. Patki, A.H., M.E. Quinones-Mateu, D. Dorazio, B. Yen-Lieberman, W.H. Boom, E.K. Thomas, and M.M. Lederman. 1996. Activation of antigeninduced lymphocyte proliferation by interleukin-15 without the mitogenic effect of interleukin-2 that may induce human immmunodeficiency virus-1 expression. J. Clin. Invest. 98:616-621.

25. Sieling, P.A., J.S. Abrams, M. Yamamura, P. Salgame, B.R. Bloom, T.H. Rea, and R.L. Modlin. 1993. Immunosuppressive roles for interleukin-10 and interleukin-4 in human infection: in vitro modulation of $\mathrm{T}$ cell responses in leprosy. J. Immunol. 150:5501-5510.

26. Pearlman, E., J.W Kazura, F.E. Hazlett, Jr., and W.H. Boom. 1993. Modulation of murine cytokine responses to mycobacterial antigens by helminth-induced T helper 2 cell responses. J. Immunol. 151:4857-4864.

27. Clerici, M., F.T. Hakim, D.J. Venzon, S. Blatt, C.W. Hendrix, T.A. Wynn, and G.M. Shearer. 1993. Changes in interleukin-2 and interleukin-4 production in asymptomatic, human immunodeficiency virus-seropositive individuals. J. Clin. Invest. 9184:759-765.

28. Clerici, M., T.A. Wynn, J.A. Berzofsky, S.P. Blatt, C.W. Hendrix, A. Sher, R.L. Coffman, and G.M. Shearer. 1994. Role of interleukin-10 in T helper cell dysfunction in asymptomatic individuals infected with the human immunodeficiency virus. J. Clin. Invest. 93:768-775.
29. Barnes, P.F., S. Fong, P.J. Brennan, P.E. Twomey, A. Mazumder, and R.L. Modlin. 1990. Local production of tumor necrosis factor and interferon- $\gamma$ in tuberculous pleuritis. J. Immunol. 145:149-154.

30. Zhang, M., Y. Lin, D.V. Iyer, J. Gong, J.S. Abrams, and P.F. Barnes. 1995. T cell cytokine responses in human infection with Mycobacterium tuberculosis. Infect. Immun. 63:3231-3234.

31. Kaufmann, S.H.E. 1988. CD8 ${ }^{+}$T lymphocytes in intracellular microbial infections. Immunol. Today. 9:168-174.

32. Flynn, J.L., M.M. Goldstein, K.J. Triebold, B. Koller, and B.R. Bloom. 1992. Major histocompatibility complex class I-restricted T cells are required for resistance to Mycobacterium tuberculosis. Proc. Natl. Acad. Sci. USA. 89: 12013-12017.

33. Stenger, S., R.J. Mazzaccaro, K. Uyemura, S. Cho, P.F. Barnes, J.-P. Rosat, A. Sette, M.B. Brenner, S.A. Porcelli, B.R. Bloom, and R.L. Modlin. 1997. Differential effects of cytolytic T cell subsets on intracellular infection. Science. 276:1684-1687.

34. Garcia, K.C., Scott, C.A., A. Brunmark, F.R. Carbone, P.A. Peterson, I.A. Wilson, and L. Teyton. 1996. CD8 enhances formation of stable T-cell receptor/MHC class I molecule complexes. Nature. 384:577-581.

35. Gao, G.F., J. Tormo, U.C. Gerth, J.R. Wyer, A.J. McMichael, D.I. Stuart, J.I. Bell, E.Y. Jones, and B.K. Jakobsen. 1997. Crystal structure of the complex between human CD8 $\alpha \alpha$ and HLA-A2. Nature. 387:630-634. 